MATTER: International Journal of Science and Technology

ISSN 2454-5880

Owofadeju, F.K., 2022

Volume 7 Issue 3, pp. 80-93

Received: 28 th July, 2021

Revised: 30 th November 2021, 17 th January 2022, 30 th January 2022

Accepted: 31 ${ }^{\text {st }}$ January 2022

Date of Publication: 02nd February 2022

DOI- https://doi.org/10.20319/mijst.2022.73.8093

This paper can be cited as: Owofadeju, F. K. (2022). Efficacy of Nigerian Grown Erythrophleum suaveolens (Gull. And Perr.) Brenan Bark Extracts as Biopreservative Against Termite Attack. MATTER: International Journal of Science and Technology, 7 (3), 80-93.

This work is licensed under the Creative Commons Attribution-NonCommercial 4.0 International License. To view a copy of this license, visit http://creativecommons.org/licenses/by-nc/4.0/ or send a letter to Creative Commons, PO Box 1866, Mountain View, CA 94042, USA.

\title{
EFFICACY OF NIGERIAN GROWN Erythrophleum suaveolens (Gull. And Perr.) Brenan BARK EXTRACTS AS BIOPRESERVATIVE AGAINST TERMITE ATTACK
}

\author{
Owofadeju, F.K. \\ Department of Wood Products Engineering, Faculty of Technology, University of Ibadan, \\ Ibadan, Nigeria \\ fem_fadeju@yahoo.com \\ fo.owofadeju@mail.ui.edu.ng
}

\begin{abstract}
Many synthetic chemicals that are used to protect wood from biodeterioration are associated with environmental pollution and toxicity to human beings. As a part of the search for less hazardous preservatives, extracts from the bark of Erythrophleum suaveolens were evaluated using ethanol extraction process. Samples of barks of Erythrophleum suaveolens were obtained from Oyo town, Nigeria. Phytochemical and elemental analyses were carried out on the oil extracts. Permeability and decay resistance tests were carried out on lumber samples of Ceiba pentandra in accordance with ASTM standards. Results were analyzed using Analysis of Variance (ANOVA) at 5\% probability level. Phytochemical analysis indicated the presence of Saponin (13.56\%), Tannin (29.71mg/g), alkaloid (6.39\%) and Total Phenol (38.71mg/g) while elemental analysis showed the presence of Copper, Iron, Lead, Magnesium and Calcium
\end{abstract}


respectively. Grave yard Test showed that the untreated Ceiba pentandra samples had the highest weight loss after 6 weeks of exposure while 100\% treatment had least weight loss. The oil extract from bark of Erythrophleum suaveolens was effective against termite attack on Ceiba pentandra wood samples and therefore has good potentials as biological preservative for wood and other lignocellulosic materials.

\section{Keywords:}

Ceiba Pentandra, Erythrophleum Suaveolens, Oil Extracts, Termite Attack, Wood Preservatives

\section{Introduction}

The demand for wood and wood products in Nigeria and the world over have continued to be on the increase, the global industrial round wood production from all types of forest for the year 2018 alone was reported to be 2.03 billion $\mathrm{m}^{3}$ (Food and Agricultural Organization, 2019). The havoc caused by fungi and certain insects on wood in service is quite devastating and ultimately results in additional labor costs to replace affected wood. Wood as a constructional material is generally treated with chemical preservatives to prevent damage by these biodeteriorating agents. The most commonly used wood preservatives presently are creosote, chromated copper arsenate (CCA), sodium pentachlorophenates (NaPCP), and inorganic arsenicals. However, many of the wood preservative chemicals have severe adverse effects on the environment and humans. There is therefore the need to find wood preservatives that are less toxic to humans, eco-friendly and cost-effective.

It has been observed that there are greater potentials in the use of plant and oil extractives as natural wood preservatives (Teaca et al, 2019, Pandey et al 2017, Broda 2020). This study, therefore, assessed the effective use of Erythrophleum suaveolens oil extracts as preservatives against termites.

\section{Literature Review}

Throughout history, wood has continued to be one of the most important renewable natural resources available to mankind. However, due to its associated structural polymers, wood is degraded by many organisms, principally fungi and termite (Schuttz and Nicholas, 2002, Sotande et al., 2011). This could limit to a great extent the utilization of wood as a structural material as the damaged wood would need replacement with time. 
Preservatives are chemicals used for the control of biodegrading agents. They are classified into three broad categories based on their inert components; the water-soluble, oil type, and the organic solvent-based preservatives, with the water-based as the most popular (Agriculture World, 2007). While the conventional wood preservatives are found to be very effective and active against wood-destroying fungi and insects, they are however toxic thereby causing environmental pollution in ways that are dangerous and harmful to plants, animals, and human beings (Kartal et al., 2004).

Increasing global concern for the environment led to the development of various friendly preservative formulation methods using biocide combinations which include inorganic-organic and organic-organic binary mixtures. Similarly, the use of extracts of some lignocellulosic materials are been researched. It has been observed that there are greater potentials in the use of plant and oil extractives as natural wood preservatives as many components of their extracts are toxic to organisms imparting decay resistance (Owofadeju and Ilesanmi, 2021).

Nurudeen et al., (2012) reported the efficacy of Zingiber officinale, Piper guinensis, and Zanthoxylum zanthoxyloides plant extracts against fungal attack on wood. In their study, it was established that the three wood species possessed potential ingredients against fungal attacks on wood. Ajala et al. (2012) investigated the potentials of Moringa oliefera extract as a wood preservative and observed that Moringa oliefera extract contained anticancer, antibacterial, and antifungi chemicals including 4-(a-L-rhamnopyranosyloxy), and benzylisothiacynate. Their study concluded that Moringa oliefera extract was effective against termite attacks on Ceiba pentandra wood. Adeduntan (2015) studied the potentials of five plants extracts; Allium salivum, Datura stamonium, Jatropha curcus, Musa acuminata and Chrysophyllum albidum against termite attack on Triplochiton scleroxylon and Gmelina arborea wood and reported that Jatropha curcus and Datura stamonium were highly effective against termite attack.

Erythrophleum suaveolens is a species of plants found in West and East Africa. The species grow up to $20 \mathrm{~m}$ in height and has rough and blackish bark. The bark contains a range of alkaloids. In high doses, the bark extract is said to be an extremely strong, rapid-acting cardiac poison, in warm-blooded animals causing shortness of breath, seizures, and cardiac arrest in a few minutes (Akinpelu et al., 2012). 


\section{Materials and Methods}

The oil extracts from Erythrophleum suavoleons were used to treat Gmelina arborea wood species. The extraction process and phytochemical analyses were conducted in the laboratories of the Department of Wood Products Engineering and Multidisciplinary Research Centre of the University of Ibadan respectively following standard procedures from relevant literatures.

\subsection{Preparation of samples}

The bark of Erythrophleum suaveolens was obtained from logs at a mill in Oyo, Nigeria (Lat. $7^{\circ} 51^{\prime} \mathrm{N}$, Long. $3^{\circ} 55^{\prime} \mathrm{E}$ ). It was identified at the herbarium unit of Forestry Research Institute of Nigeria (FRIN), Ibadan, and thereafter sun-dried for two weeks, ground, and sieved to $0.001 \mathrm{~mm}$ size. The wood sample of Ceiba pentandra was obtained at a plank market in Ibadan, Nigeria, planed and cut to sizes $15 \times 25 \times 50 \mathrm{~mm}$. The weighed wood samples were oven-dried at $102 \pm 3^{\circ} \mathrm{C}$ for 24hours.

\subsection{Extraction Process of Oil Extracts}

This was carried out on 100g of ground samples of Erythrophleum suaveolens following AOCS (1995) Standard using ethanol as the solvent, at $70^{\circ} \mathrm{C}$, for 16 hours. The oil obtained was concentrated to $100 \%$ at $74^{\circ} \mathrm{C}$ for 3hours using Rotary Evaporator, digested, and analyzed to determine its active ingredients. The extract residue was dried and weighed to determine the percentage yield of the oil using the formula,

$$
\text { percentage yield }=100-\left(\frac{\text { weight of the sample residue }}{\text { weight of sample before extraction }} \times 100\right)
$$

\subsection{Oil Extracts Elemental Analysis}

The elemental analysis of the oil extracts was carried out following AOAC (1990). Five grams of milled samples were pyrolyzed in a furnace at $550^{\circ} \mathrm{C}$ for 24 hours. Concentrated $\mathrm{HCl}$ (2ml) and a few drops of $\mathrm{HNO}_{3}$ were added to melt the resulting ash and the solution was evaporated almost to dryness. The dry elements were diluted with distilled water and analyzed. Flame photometry method was employed in the determination of the Lead $(\mathrm{Pb})$ and Magnesium $(\mathrm{Mg})$ while $\mathrm{Iron}(\mathrm{Fe})$, Calcium $(\mathrm{Ca})$, and Copper $(\mathrm{Cu})$ were analyzed by Atomic Absorption Spectrophotometer method

\subsection{Qualitative Phytochemical Screening}

Qualitative phytochemical screening of oil extracts generated from bark of Erythrophleum suaveolens was conducted for saponin, tannin, flavonoid, steroid, phlobatannins, 
terpenoid, coumarin, emodin, anthraquinone, anthocyanins, alkaloid, and cardiac glycosides following classical methods specified by Manjulika et al. (2014) as described in Table 1 while ferric chloride and ammonium hydroxide tests were carried out to determine the charcones and phenols respectively, as reported by Trease and Evans (2004).

Table 1: Procedure for the qualitative phytochemical screening of oil extracts

\begin{tabular}{|c|c|}
\hline Phytoconstituents & Test \\
\hline Saponins & $5 \mathrm{ml}$ extract $+5 \mathrm{ml} \mathrm{H}_{2} \mathrm{O}+$ heat \\
\hline Tannins (Braymer's Test) & $2 \mathrm{ml} \mathrm{extract}+2 \mathrm{ml} \mathrm{H}_{2} \mathrm{O}+2-3$ drops $\mathrm{FeCl}_{3}(5 \%)$ \\
\hline Flavonoids & $1 \mathrm{ml}$ extract $+1 \mathrm{ml} \mathrm{Pb}(\mathrm{OAc})_{4}(10 \%)$ \\
\hline Steroids & $2 \mathrm{ml} \mathrm{extract}+2 \mathrm{ml} \mathrm{CHCl}_{3}+2 \mathrm{ml} \mathrm{H}_{2} \mathrm{SO}_{4}$ (conc.) \\
\hline Phlobatannins & $2 \mathrm{ml}$ extract $+2 \mathrm{ml} \mathrm{HCl}(1 \%)+$ heat \\
\hline Terpenoids & $2 \mathrm{ml} \mathrm{extract}+2 \mathrm{ml}\left(\mathrm{CH}_{3} \mathrm{CO}\right)_{2} \mathrm{O}+2-3$ drops conc. $\mathrm{H}_{2} \mathrm{SO}_{4}$ \\
\hline Coumarins & $2 \mathrm{ml}$ extract $+3 \mathrm{ml} \mathrm{NaOH}(10 \%)$ \\
\hline Emodins & $2 \mathrm{ml}$ extract $+2 \mathrm{ml} \mathrm{NH}_{4} \mathrm{OH}+3 \mathrm{ml}$ Benzene \\
\hline Anthraquinones & $3 \mathrm{ml}$ extract $+3 \mathrm{ml}$ Benzene $+5 \mathrm{ml} \mathrm{NH} 3(10 \%)$ \\
\hline Anthocyannins & $2 \mathrm{ml}$ extract $+2 \mathrm{ml} \mathrm{HCl}(2 \mathrm{~N})+\mathrm{NH}_{3}$ \\
\hline Alkaloids & $2 \mathrm{ml}$ extract + few drops of Hager's reagent \\
\hline Cardiac glycosides & $2 \mathrm{ml} \mathrm{extract}+2 \mathrm{ml} \mathrm{CHCl}_{3}+2 \mathrm{ml} \mathrm{CH}_{3} \mathrm{COOH}$ \\
\hline
\end{tabular}

(Source: Manjulika et al., 2014)

\subsection{Quantitative Phytochemical Screening}

The quantitative phytochemical screening was done on four of the phytoconstituents that were confirmed positive in the oil extracts of Erythrophleum suaveolens to determine their percentage compositions: these were saponin, total alkaloids, and total phenol and tannin contents respectively

\subsubsection{Saponin Content determination}

The determination of saponin content of the oil extracts was done adopting the method reported by Obadoni and Ochuko (2011). To 20g of each sample was added 100ml of $20 \%$ aqueous ethanol and the mixture was heated at $55 \mathrm{C}^{\circ}$ for 4 hours. The mixture was filtered, and the residue was re-extracted with $200 \mathrm{ml} 20 \%$ aqueous ethanol. The combined extracts were 
concentrated to $40 \mathrm{ml}$ and separated by the addition of $20 \mathrm{ml}$ of di-ethyl ether. The aqueous layer was recovered while the ether layer was discarded. The recovered solution was extracted with nbutanol and washed with $10 \mathrm{ml}$ of $5 \%$ aqueous sodium chloride. The remaining solution was concentrated, oven-dried, and the weighed content was calculated as percentage saponin.

\subsubsection{Total Alkaloids determination}

Total alkaloids percentage was determined by the Harborne (1998) method. $200 \mathrm{ml}$ of $10 \%$ acetic acid in ethanol was added to $5 \mathrm{~g}$ of the sample. The mixture was left covered for 4 hours, filtered, and the extract was concentrated to one-quarter of the original volume. Concentrated ammonia water was added dropwise to the extract until the precipitation was complete. The whole solution was left to settle and the precipitated was collected and washed with dilute ammonium hydroxide and then filtered. The residue obtained was oven-dried and weighed as a percentage alkaloid.

\subsubsection{Total Phenolic Content determination}

Folin-Ciocalteu assay method as reported by Singleton et al. (1999) was used for the determination of the total phenol content. To $10 \%$ water solution of extract was added $1 \mathrm{ml}$ of Folin-Ciocalteu phenol reagent and the mixture was left for 5 minutes. $10 \mathrm{ml}$ of $7 \%$ Sodium carbonate $\left(\mathrm{Na}_{2} \mathrm{CO}_{3}\right)$ solution was added to the mixture and the volume was made up to $25 \mathrm{ml}$. A set of standard solutions of Gallic acid $(20,40,40,60,80$, and $100 \mu \mathrm{g} / \mathrm{ml})$ were prepared in the same manner and used as reference. The samples were incubated for 90 min at $25^{\circ} \mathrm{C}$ and the absorbance for test and standard solutions were determined.

\subsubsection{Tannin Content determination}

The tannins were determined by Folin - Ciocalteu method as reported by Singleton et al (1999). $0.1 \mathrm{ml}$ of the sample solution was added to a volumetric flask $(10 \mathrm{ml})$ containing $7.5 \mathrm{ml}$ of distilled water and $0.5 \mathrm{ml}$ of Folin-Ciocalteu phenol reagent. $1 \mathrm{ml}$ of $35 \% \mathrm{Na}_{2} \mathrm{CO}_{3}$ solution was added and the mixture was diluted to $10 \mathrm{ml}$ with distilled water and kept at $25^{\circ} \mathrm{C}$ for 30 min. similarly, solutions of gallic acid $(20,40,60,80$, and $100 \mu \mathrm{g} / \mathrm{ml})$ were prepared as standard using the same procedure. Absorbance for test and standard solutions were measured to determine the tannin content.

\subsection{Percentage Absorption determination}


The test block samples were soaked inside the oil extracts and diluent through the coldsoaking method following the method employed by Adeduntan (2015) for 24hours at room temperature at concentration levels $0 \%, 25 \%, 50 \%, 75 \%$, and $100 \%$, and the percentage absorption determined using the formula.

$$
\text { Absorption rate }=\frac{w 3-W 2}{w 2} \times 100
$$

where $\mathrm{W}_{3}=$ weight of wood after immersion

$$
\mathrm{W}_{2}=\text { weight of wood after oven-dry }
$$

\subsection{Wood samples decay test}

The decay test was in accordance with ASTM D3345-17 standard. The wood samples (treated and control) were exposed to termite attack in a termitarium within the University of Ibadan, Nigeria, and visually observed weekly for 6 weeks. Percentage weight losses were calculated using the formula,

$$
\text { Weight } \operatorname{loss}(\%)=\frac{T 3-T 4}{T 3} \times 100
$$

Where T3= weight after preservative application

T4= weight after exposure to termite attack.

\section{Results and Discussion}

The percentage oil yield from the bark of Erythrophleum suaveolens after extraction was found to be $41 \%$ and this signifies a high yield from the extraction process. The result is similar to the results reported by Ogboru et al., 2017 who reported an oil yield of 39\% for Erythrophleum ivorense and suggested it to be of moderate-high yield.

The mineral element analysis of oil extracts from the bark of Erythrophleum suaveolens is shown in Table 2. Copper, which is an active biocide was present in the oil extracts although not in appreciable quantity $(0.005 \pm 0.05 \mathrm{ppm})$. other mineral elements present in the bark were of higher concentrations than that of $\mathrm{Cu}$.

Table 2: Mineral Element Analysis of oil extract from the bark of Erythrophleum suaveolens

\begin{tabular}{cc}
\hline Mineral Elements in Oil Extracts & Ppm \\
\hline Copper & $0.005 \pm 0.05$ \\
Iron & $0.303 \pm 0.14$
\end{tabular}


Lead

Magnesium

Calcium
$0.013 \pm 0.01$

$0.182 \pm 0.02$

$0.053 \pm 0.04$

\section{(Source: Self)}

The qualitative phytochemical screening of the oil extracts revealed the presence of saponin, tannin, terpenoids, coumarin, alkaloids, cardiac glycosides, and phenols respectively (Table 3). These chemicals are environmentally friendly preservatives when they bond with $\mathrm{Cu}$ and $\mathrm{Zn}$ and could make non-toxic preservatives suitable for humans and other applications (Owofadeju and Alawode, 2016). Table 4 shows some of these phytochemicals in quantitative terms. This study revealed high concentrations of the phytochemicals in the oil extracts of the bark of the wood species, and this is an indication of the potentials of the bark extracts of Erythrophleum suaveolens as a preservative.

Table 3: Qualitative Phytochemicals Screening of the oil extracts from the bark of Erythrophleum suaveolens

\begin{tabular}{lcc}
\hline & Phytochemicals & Inference \\
\hline $\mathbf{1}$ & Saponin (Foam Test) & $+\mathrm{ve}$ \\
$\mathbf{3}$ & Tannin (Braymer's Test) & $+\mathrm{ve}$ \\
$\mathbf{4}$ & Flavonoid (Lead acetate Test) & -ve \\
$\mathbf{5}$ & Steroid (Salkowaski's Test) & $+\mathrm{ve}$ \\
$\mathbf{6}$ & Phlobatannin (Precipitate test) & -ve \\
$\mathbf{7}$ & Terpenoid (Salkowaski's test) & $+\mathrm{ve}$ \\
$\mathbf{8}$ & Emodin (Reaction with Ammonium hydroxide and benzene) & $+\mathrm{ve}$ \\
$\mathbf{9}$ & Anthraquinone (Borntrager's Test) & -ve \\
$\mathbf{1 0}$ & Anthocyanins (Reaction with Acid and Ammonia) & -ve \\
$\mathbf{1 1}$ & Alkaloid (Hager's Test) & -ve \\
$\mathbf{1 2}$ & Cardiac Glycosides (Legal's Test) & $+\mathrm{ve}$ \\
$\mathbf{1 3}$ & Charcones (Ammonium hydroxide's Test) & $+\mathrm{ve}$ \\
$\mathbf{1 4}$ & Phenols (Ferric Chloride's Test) & -ve \\
\hline
\end{tabular}

(Source: Self) 
Table 4: Quantitative Phytochemicals Screening of the oil extracts from the bark of Erythrophleum suaveolens

\begin{tabular}{lc}
\hline Phytochemical & Concentration \\
\hline \% Saponin & 13.557 \\
Tannin (mg GAE / g) & $29.706 \pm 0.277$ \\
$\%$ Alkaloid & 06.39 \\
Total Phenol (mg GAE / g) & $38.710 \pm 0.00$ \\
\hline
\end{tabular}

(Source: Self)

Results from ANOVA in Table 5 showed that the rate of absorption of wood samples at different concentration levels varies. This revealed that there were significant differences among the concentration levels at a 5\% level of probability. The difference in absorption rate could be due to differences in concentration of the preservative, wood species, and moisture content of wood sample as buttressed by Ajala et al. (2012). Islam et al. (2008) reported that the treatability of wood could be influenced by the viscosity and temperature of the preservative employed as well as the treatment methods and duration of treatment.

Analysis of variance for percentage weight loss of wood samples treated with different concentration levels is presented in Table 6. It shows there were significant differences among the treatments at the 0.05 probability level. Further test by Duncan Multiple Range (Table 7) revealed that $75 \%, 25 \%, 50 \%$, and $0 \%$ concentration levels are not too significantly different from $100 \%$ concentration but different from the control. This is related to the work reported by Ajala et al. (2012) about the rate of termite attack against test samples treated with Moringa oleifera seed oil.

Table 5: Analysis of Variance for absorption rate at 0\%, 25\%, 50\%, 75\% and 100 concentration levels

\begin{tabular}{cccccc}
\hline $\begin{array}{c}\text { Sources of } \\
\text { variance }\end{array}$ & $\begin{array}{c}\text { Degree of } \\
\text { freedom }\end{array}$ & $\begin{array}{c}\text { Sum of } \\
\text { square }\end{array}$ & $\begin{array}{c}\text { Mean of } \\
\text { square }\end{array}$ & Fcal & Sig. \\
\hline Treatment & 4 & 43381.815 & 10845.454 & 18.504 & $0.000^{*}$ \\
\hline
\end{tabular}




$\begin{array}{llll}\text { Error } & 20 & 11722.122 & 586.106\end{array}$

$\begin{array}{lll}\text { Total } & 24 & 55103.937\end{array}$

(Source: Self)

Table 6: Analysis of Variance for weight loss at 0\%, 25\%, 50\%, 75\% and 100\% concentration levels

\begin{tabular}{llcccc}
\hline $\begin{array}{c}\text { Sources of } \\
\text { variance }\end{array}$ & $\begin{array}{c}\text { Degree of } \\
\text { freedom }\end{array}$ & $\begin{array}{c}\text { Sum of } \\
\text { square }\end{array}$ & $\begin{array}{c}\text { Mean of } \\
\text { square }\end{array}$ & Fcal & Sig. \\
\hline Treatment & 5 & 2869.689 & 573.938 & 4.894 & $0.003^{*}$ \\
Error & 24 & 2814.801 & 117.283 & & \\
Total & 29 & 5684.490 & & & \\
\hline
\end{tabular}

(Source: Self)

Table 7: Follow-up Multiple Range Test of weight loss

\begin{tabular}{cc}
\hline Concentration level $(\%)$ & Mean value grouping \\
\hline $100 \%$ & $19.6862^{\mathrm{a}}$ \\
$75 \%$ & $28.0061^{\mathrm{ab}}$ \\
$50 \%$ & $38.7884^{\mathrm{bc}}$ \\
$25 \%$ & ${30.1623^{\mathrm{bc}}}^{\mathrm{c}}$ \\
$0 \%$ & $41.6253^{\mathrm{bc}}$ \\
Control & $49.9544^{\mathrm{c}}$ \\
\hline
\end{tabular}

(Source: Self)

The control (untreated samples) group had the highest weight loss which indicated that the level of attack of untreated wood samples by termites is significantly more than that of treated test samples. Wood samples treated with Erythrophleum suaveolens bark oil extracts level of $100 \%$ had the lowest weight loss which is an indication that the concentration level was most effective in suppressing the rate of attack of termites. This is similar to the findings of Obomanu et al. (2005), who also reported increased weight loss with an increase in the extract concentration level of Lepidagathis alopecuroides extracts.

Wood preservatives efficiency and effectiveness depend on the active ingredients of the preservative as well as the depth of penetration, distribution and retention properties of the wood 
being subjected to preservative treatment. Some active components of Erythrophleum suaveolens bark extract has been reported to be highly poisonous Akinpelu et al., (2012), therefore it can be inferred that the resistance of the wood samples to termite attack was probably due to the active components in the oil.

\section{Conclusion}

The oil extracts from the bark of Erythrophleum suaveolens had considerable effectiveness against termite attack on Ceiba pentandra wood samples at varying concentration levels, hence could be used as a biological preservative for wood. The minimal range of effectiveness levels was between 75 and $100 \%$ of the oil extract with the least termite attack at $100 \%$.

\subsection{Research Limitations}

While this study successfully investigated the potentials of Erythrophleum suaveolens bark extracts as wood preservatives, the work could not determine the extractive contents of the other components of the wood species such as the seed, the root, leaves, and the heartwood to determine their phytochemical percentage composition. The cold soak method was employed in the impregnation of the preservative to the wood test samples, this might not have given the most effective retention of preservative on the test samples. Also, the study could not determine the leachability of the preservative due to the time frame of the work.

\subsection{Scope of Further Research}

There is a need for further research on Erythrophleum suaveolens extract from its roots, leaves, and other parts of the plant. Moreover, properties such as the leachability of the preservative using different wood species should be investigated as well as the preservative's toxicity on humans.

\section{REFERENCES}

Adeduntan, S.A. (2015). The termicidal effect of some plant materials on some selected wood species. International Journal of Biological and Chemical Sciences, 9 (2), 986-995. https://doi.org/10.4314/ijbcs.v9i2.34

Agriculture World 2007. Wood preservation: the latest development research project, Forest 
Research Institute Malaysia (FRIM). Retrieved April 15, 2008 from

http://agricultureresearch. Blogspot. Com/2007_1201_Archive html.

Ajala, O. O., Adebawo, F. G., \& Olayiwola, Y. B. (2012). Potential of Moringa oleifera Lam. seed oil as a bio-preservative agent against attack on Aningeria robusta Wood (A. Chev). Proceedings of the $3^{\text {rd }}$ Biennial Nat. Conf. of the Forests and Forest Products Society held at University of Ibadan, Ibadan, Nigeria $3^{\text {rd }}-6^{\text {th }}$ April, 2012.

Akinpelu, B. A., Dare, C. A., Adebesin, F. I., Iwalewa, E. O. \& Oyedapo, O. O. (2012): Effect of stem bark of Erythrophleum suaveolens (Guill. And Perri.) saponin on fresh water snail (Labistes lybicus) tissues. African Journal of Environmental Science and Technology, 6 (11), 446-451.

AOAC, 1990. Official method of analysis of association of official analytical chemists, Association of Official Analytical Chemist. (14 ${ }^{\text {th }}$ Ed.), Arlington, VA.

American Oil Chemists Society, (1995). Official and Recommended Methods of American Oil Chemists Society $4^{\text {th }}$ Edition, Champaigne II. AOCS Press

ASTM, (2017). ASTM D3345-17, Standard test method for laboratory evaluation of solid wood for resistance to termites, ASTM International, West Conshohocken, PA, 2017, www.astm.org.

Broda M. (2020). Natural Compounds for Wood Protection against Fungi - A Review. Molecules. Ncbi.nlm.nih.gov/pmc https://doi.org/10.3390/molecules25153538

Food and Agriculture Organization (FAO), (2019). FAO Yearbook of Forest Products 2019. Www.fao.org/forestry/statistics. Accessed on May 21, 2021

Harborne, J. B. (1998). Textbook of Phytochemical Methods. A Guide to Modern Technique of Plant Analysis (pp. 21-72) London, U.K. Chapman and Hall Ltd.

Islam, M.N., Ando, K., Yamauchi, H., Kobayashi,Y.and Hattori,N.(2008):Comparative Study between full cell and passive impregnation Method of Preservatiom for laser incised Douglas fir lumber. Journal of Wood Science, 42: 343-.350

Kartal, S. N., Imamura, Y., Tsuchiya, F., \& Ohsata, K., (2004): Preliminary evaluation of fungicidal and termicidal activities of filtrates from Biomass Slurry from fuel production. Journal of Bioresources and Technology, 95 (1), 41-47. 
Manjulika, Y., Sanjukta, C., Sharad, K.G. and Geeta W. (2014): Preliminary phytochemical screening of six medicinal plants used in traditional medicine. International Journal of Pharmacy and Pharmaceutical Sciences. 6 (5): 539-542

Nurudeen, T. A., Abiola, J. K., Ekpo, E. N., Olasupo, O. O., Haastrup, N. O. and Okunrotifa, A. O., 2012: Effects of plant extracts as preservative against wood decay fungus Sclerotium rolfsii (Sacc). Journal of Forestry Research and Management 2012(9):7382.

Obadoni, B. O. \& Ochuko, P. O. (2001): Phytochemical studies and comparative efficacy of the crude extracts of some homostatic plants in Edo and Delta States of Nigeria. Global J. Pure Appl. Sci. 8b, 203-208.

Obomanu, F. G., Fekarurhobo, G. K., \& Howard, I. C. (2005): Antimicrobial activity of extracts of Lepidagathis alopecuroides (valil). Journal of Chemical Society of Nigeria, 30 (1), 33-35

Ogboru, R. O., Akindeno, C. O. \& Owoeye, E. A. (2017): Chemical composition and medicinal potentials of the bark of Erythrophleum ivorense A. chev. Journal of Bioscience and Biotechnology Discovery. 2, 15-20.

Owofadeju, F.K. \& Alawode, O.A. (2016). Evaluation of vetiver (Vetivera nigritana) plant extract as an ecofriendly wood preservative. AZOJETE, 12. 49-57

Owofadeju, F.K. and Ilesanmi, O.A. 2020. Efficacy of oil extract from sweet orange (Citrus sinensis) peels and seeds as a natural wood preservative. Nigerian Journal of Forestry. Vol 50:1.

Pandey, A.K., Kumar P., Singh, P., Tripathi N.N., \& Bajpai, V.K. (2017). Essential oils: Sources of antimicrobials and food preservatives. Front.Microbiol.7, 2161. https://doi.org/10.3389/fmicb.2016.02161

Schuttz, T. P. and Nicholas, O. D. 2002: Development of environmental preservations based on the combination of organic biocides with co-oxidants and metal chelators Phytochemistry, 6:555-560

Singleton, V. L., Orthofer, R. \& Lamuela-Raventos, R. M. (1999): Analysis of total phenols and other oxidation substrates and antioxidants by means of Folin- Ciocalteau reagent. Method, Enzymol, 299, 152-178.

Sotannde, O. A., Yager, O. G., Zira, D. B. and Usman A. 2011: Termiticidal effects of neem 
extracts on the wood of Khaya senegalensis. Research Journal of Forestry. 2011: 5(3): 128-138.

Teaca C.A., Rosu, D., Mustata, F., Rusu, T., Rosu L., Rosca I. \& Varganici C.D. (2019). Natural bio-based products for wood coating and protection against degradation: A Review. BioResources 14, 487-490

Trease, E. and Evans, W. C. (2004). Pharmacognosy, William Charles Evans Fifteenth edition, Saunders Publisher, London. 34-440. ISBN-10:81- 312-0087-6. 